\title{
The Potential Effect of the IDH1 Mutation and MGMT Gene Promoter Methylation on the Control of Glioblastoma-Associated Epilepsy in Patients Receiving Anti-Epileptic Agents and Chemotherapies
}

\author{
(1) Maher KURDI, ${ }^{1}$ (1) Nadeem Shafique BUTT, ${ }^{2}$ (1) Saleh BAEESA, ${ }^{3}$ (1) Badrah ALGHAMDI, ${ }^{4}$ \\ (b) Yazid MAGHRABI, ${ }^{5}$ (1) Anas BARDEESI, ${ }^{5}$ (1) Rothaina SAEEDI, ${ }^{3}$ (1) Fahad ALGHAMDI, ${ }^{6}$ \\ (D) Najla ALGHANMI,7 (1) Mohammed BARI, 이 Alaa SAMKARI, (1) Ahmed LARY, \\ (1) Taghreed ALSINANI, ${ }^{10}$ (1) Sahar HAKAMY ${ }^{11}$
}

\author{
'Department of Pathology, King Abdulaziz University Faculty of Medicine in Rabigh, Kingdom of Saudi Arabia \\ 2Department of Family and Community Medicine, King Abdulaziz University Faculty of Medicine in Rabigh, Jeddah, Kingdom of Saudi Arabia \\ ${ }^{3}$ Division of Neurosurgery, King Abdulaziz University Faculty of Medicine, Jeddah, Kingdom of Saudi Arabia \\ ${ }^{4}$ Department of Physiology, King Abdulaziz University Faculty of Medicine, Jeddah, Kingdom of Saudi Arabia \\ ${ }^{5}$ Department of Neuroscience, King Faisal Specialist Hospital and Research Center, Jeddah, Kingdom of Saudi Arabia \\ ${ }^{6}$ Department of Pathology, King Abdulaziz University Faculty of Medicine, Jeddah, Kingdom of Saudi Arabia \\ ${ }^{7}$ Department of Pathology, King Abdulaziz University Hospital, Jeddah, Kingdom of Saudi Arabia \\ ${ }^{8}$ Department of Pathology and Laboratory Medicine, King Saud Bin Abdulaziz University for Health Science, Jeddah, Kingdom of Saudi Arabia \\ 'Section of Neurosurgery, Department of Surgery, King Abdulaziz Medical City, Jeddah, Kingdom of Saudi Arabia \\ ${ }^{10}$ Division of Neurosurgery, King Fahad General Hospital, Jeddah, Kingdom of Saudi Arabia \\ ${ }^{11}$ Center of Excellence in Genomic Medicine Research, King Abdulaziz University, Jeddah, Kingdom of Saudi Arabia
}

\begin{abstract}
Objectives: (a) The objective of the study was to assess the control of seizure in glioblastoma patients receiving anti-epileptic drugs and chemotherapies after total resection and its association with O-methylguanine-DNA methyltransferase (MGMT) promoter methylation and the isocitrate dehydrogenase 1 (IDH1) mutation; (b) to determine which anti-epileptic drug exerts the best effective control on glioblastoma-associated epilepsy; and (c) to identify the relationship between seizure control and anti-epileptic drugs with recurrence interval.

Methods: This was a retrospective cohort study of patients with postoperative glioblastoma-associated epilepsy. The correlation between IDH1 mutation and MGMT methylation with anti-epileptic drugs, chemotherapy type, seizure control, and recurrence interval was analyzed.

Results: The study included 53 patients with glioblastoma-associated epilepsy. IDH1 mutation was present in 20 patients, and MGMT methylation was present in 13 patients. 37 cases received chemoradiotherapy while 16 cases received only radiotherapy. Levetiracetam was the most prescribed anti-epileptic drug $(n=36,60 \%)$, and 36 and 16 patients had controlled and uncontrolled seizures, respectively. IDH1 mutation and unmethylated MGMT were significantly present in cases with controlled epilepsy $(p<0.05)$. Levetiracetam showed significantly better seizure control in cases with IDH1 mutation and unmethylated MGMT promotor $(p<0.05)$.

Conclusion: (a) Glioblastoma-associated epilepsy can be better controlled in patients with the IDH1 mutation and unmethylated MGMT, (b) levetiracetam was the first-line anti-epileptic drug for controlling seizure, (c) lack of seizure control in glioblastoma patients may not be related to tumor recurrence despite 1-year treatment, and (d) better understanding of the risk factors associated with glioma-associated epilepsy are needed to improve patient quality of life.
\end{abstract}

Keywords: Anti-epileptic drugs; epilepsy; glioblastoma; IDH1 mutation; MGMT promotor methylation; temozolomide.

Cite this article as: Kurdi M, Butt NS, Baeesa S, Alghamdi B, Maghrabi Y, Bardeesi A, et al. The Potential Effect of the IDH1 Mutation and MGMT Gene Promoter Methylation on the Control of Glioblastoma-Associated Epilepsy in Patients Receiving Anti-Epileptic Agents and Chemotherapies. Epilepsi 2021;27:155-162.

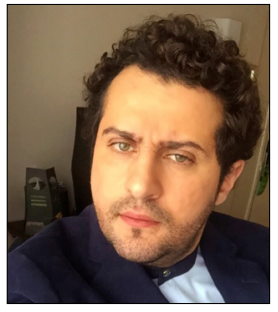

Corresponding author Maher KURDI, M.D.

e-mail ahkurdi@kau.edu.sa

Received 20.04.2021

Accepted 31.05.2021

Online date 30.07.2021

Content of this journal is licensed under a Creative Commons Attribution-NonCommercial 4.0 International License.

Maher KURDI, M.D.

\section{Introduction}

Glioblastoma-associated epilepsy is an uncommon feature of infiltrative gliomas, and approximately $30 \%$ of cases are drug-resistant even after surgical resection. ${ }^{[1-3]}$ The cause remains unclear; however, it is likely that genetic factors of the peritumoral brain tissue are responsible for these seizure activities. ${ }^{[4-6]}$ There is evidence that tumor growth may stimulate the epileptic focus, suggesting that both condi- 


\section{Anti-Epileptik Ajanlar ve Kemoterapi Alan Hastalarda IDH1 Mutasyonu ve MGMT Gen Promoter Metilasyonunun Glioblastom ile İlişkili Epilepsinin Kontrolü Üzerindeki Potansiyel Etkisi}

\section{Öz}

Amaç: (a) Total rezeksiyondan sonra anti-epileptik ilaçlar ve kemoterapi alan glioblastom hastalarında nöbet kontrolünü, ve bunun O-metilguanin-DNA-metiltransferaz (MGMT) promoter bölgesinde metilasyon ve izositrat dehidrogenaz 1 (IDH1) mutasyonu ile ilişkisini değerlendirmek; (b) hangi anti-epileptik ilacın glioblastom ile ilişkili epilepsi üzerinde en etkili kontrolü sağladığını belirlemek; (c) nöbet kontrolü ve antiepileptik ilaçlar arasındaki ilişkiyi rekürrens aralığı ile belirlemek.

Gereç ve Yöntem: Bu, glioblastom ile ilişkili ameliyat sonrası epilepsisi olan hastaların geriye dönük bir kohort çalışmasıdır. IDH1 mutasyonu ile MGMT metilasyonu ile antiepileptik ilaçlar, kemoterapi tipi, nöbet kontrolü ve rekürrens aralığı arasındaki korelasyon analiz edildi.

Bulgular: Çalışmaya glioblastom ile ilişkili epilepsisi olan 53 hasta dahil edildi. Yirmi hastada IDH1 mutasyonu, 13 hastada MGMT metilasyonu mevcuttu. Otuz yedi olgu kemoradyoterapi alırken 16 olgu sadece radyoterapi almıştı. En çok reçete edilen anti-epileptik ilaç levetirasetam idi $(n=36, \% 60)$ ve sırasıyla 36 ve 16 hastada kontrollü ve kontrolsüz nöbetler mevcuttu. Kontrollü nöbeti olan olgularda IDH1 mutasyonu ve metillenmemiş MGMT anlamlı oranda mevcuttu $(p<0.05)$. Levetirasetam, IDH1 mutasyonu ve metillenmemiş MGMT promoteri olan olgularda önemli ölçüde daha iyi nöbet kontrolü sağladı $(p<0.05)$.

Sonuç: (a) IDH1 mutasyonu ve metillenmemiş MGMT'si olan hastalarda glioblastom ile ilişkili epilepsi daha iyi kontrol edilebilir, (b) Levetirasetam, nöbet kontrolünde ilk seçenek anti-epileptik ilaçtı, (c) Bir yıllık tedaviye rağmen glioblastom hastalarında nöbet kontrolünün olmaması, tümör rekürrensi ile ilişkili olmayabilir, (d) Hastanın yaşam kalitesini iyileştirmek için gliom ile ilişkili epilepsi ile ilişkili risk faktörlerinin daha iyi anlaşılmasına ihtiyaç vardır.

Anahtar sözcükler: Anti-epileptik ilaçlar; epilepsi; glioblastom; IDH1 mutasyonu; MGMT promoter metilasyonu; temozolomid.

tions share common mechanisms. ${ }^{[5]}$ Another possible explanation is the association of gliomas with the isocitrate dehydrogenase 1 (IDH1) mutation. The previous studies showed that IDH1-mutant gliomas are more likely to cause seizures than IDH1-wildtype (wt) gliomas, as the mutant enzyme reduces a-ketoglutarate to D-2-hydroxyglutarate. Hence, D-2-hydroxyglutarate over production has been suggested to play a role in the neuronal excitation leading to seizures ${ }^{[6-8]}$ While the association of the IDH1 mutation with preoperative seizures has been previously reported, the influence of the IDH1 mutation in the post-operative glioma microenvironment is not yet investigated. Several therapeutic strategies failed to control the seizure activity, ${ }^{[9]}$ thus a better understanding of the risk factors and mechanisms of glioma-associated epilepsy are needed to improve patient quality of life.

Gliomas with O6-methylguanine-DNA methyltransferase (MGMT) gene promoter methylation are more treatment-sensitive to temozolomide (TMZ) chemotherapy. ${ }^{[10]}$ However, the association of glioma-associated epilepsy with MGMT promotor methylation has not been extensively studied. Patients with MGMT methylated gliomas show more seizure control than those with non-methylated MGMT. ${ }^{[11]}$

In this study, we assessed seizure control among glioblastoma patients, after total resection, receiving different anti-epileptic drugs and chemotherapies and investigated its associations with MGMT promotor methylation and the
IDH1 mutation. Levetiracetam is considered the first-line drug to control seizures in glioma patients, proven as the most potent MGMT inhibitor among anti-epileptic medications. ${ }^{[12]}$ Several studies concluded that levetiracetam and valproic acid are the main anti-epileptic drugs that exhibit antitumor effects which decrease mortality rate among glioblastoma patients with epilepsy ${ }^{[13-18]}$ In this current study, we investigated which anti-epileptic drug exerted the best effective control of glioblastoma-associated epilepsy among Saudi population. We also identified the relationship of seizure control with different anti-epileptic drugs and the recurrence interval. The only limitations we faced in this current study were the small number of glioblastoma-associated seizure and the unknown biological cause of seizure progression or patient death when they showed late recurrence. We believe this because glioblastoma associated epilepsy is generally rare.

\section{Materials and Methods}

Patient stratification- This study included 53 patients with glioblastoma-associated epilepsy from two medical hospitals in Saudi Arabia in the period between 2014 and 2019. This study was ethically approved by the National Biomedical Ethics Committee at King Abdulaziz University (HA-02-J-008). All patients underwent total surgical resection of the tumor followed by a standard protocol of adjuvant therapies. The histological diagnosis was made according to the classification of the World Health Organization. Clinical data were retrieved from hospital records, including patients' age at diagnosis, gender, post-oper- 
ative adjuvant therapies, anti-epileptic medications, history of seizure control, and MGMT methylation profile. The patients were stratified into different groups based on the types of chemotherapies and anti-epileptic drugs. Standard radiotherapy with a total dose of 60 Gy and TZM (150-200 $\mathrm{mg} / \mathrm{m}^{2}$ for $6-12$ cycles) was administered to all patients at the time of management. The study excluded glioblastoma cases that are: (a) Not presented with seizure, (b) not completely resected, and/or (c) cases did not receive any type of adjuvant therapies. All cases had MGMT methylation status. Unfortunately, all patients who had recurrence have died. Patients who showed no recurrence for more than 1 year eventually passed away because of other associated comorbidities.

Tumor samples- Archival routine formalin-fixed and paraffin-embedded tumor tissues were collected from 53 patients diagnosed with glioblastoma-associated epilepsy. Hematoxylin-and-eosin-stained sections were re-examined by a certified neuropathologist (MK) to assure the histopathological diagnosis followed the WHO's classification. Unstained positive-charged slides from 46 tissue blocks were prepared for IDH1 immunostaining.

Immunohistochemistry for IDH1- To qualitatively identify wt and mutant IDH1 in tissue sections on an automated slide stainer, the mouse monoclonal antibody anti-IDH1 $\mathrm{R} 132 \mathrm{H}$ (clone H09) and OptiView detection kit from Ventana on a BenchMark XT automated staining system were used. The assay procedure consisted of deparaffinization with $E Z$ Prep at $75^{\circ} \mathrm{C}$, heat pre-treatment with Cell Conditioner for
$68 \mathrm{~min}$, and incubation with 1:20-1:50 diluted antibody for $32 \mathrm{~min}$ at $37^{\circ} \mathrm{C}$. The slides were counterstained with Hematoxylin II for $16 \mathrm{~min}$, and bluing reagent was used for $16 \mathrm{~min}$. Afterward, the slides were removed from the slide stainer and then immersed into successive alcohol buffers at different concentrations for $3 \mathrm{~min}$. Sections in which $>10 \%$ of tumor cells were positively stained were defined as IDH1-mutant (Fig. 1).

Statistical analysis- Data were described as frequencies and percentages. The recurrence interval was calculated from the time of adjuvant therapy initiation after surgical resection until the $1^{\text {st }}$ day of tumor recurrence. The Pearson's Chi-square test was used to explore the associations between the IDH1 mutation, MGMT promotor methylation status, seizure control, anti-epileptic drug, and chemotherapy with various study factors. Kaplan-Meier curves and log-rank tests were used to compare the distribution of recurrence times. All statistical analyses in this study were performed using IBM SPSS1 ver. 24 statistical software programs (SPSS Inc., Chicago, IL).

\section{Results}

Descriptive analysis- In total, 53 post-operative patients with glioblastoma-associated seizures were included in this study (36 men and 17 women). The mean age was 51 years. The predominant locations were the frontal $(n=21,39.6 \%)$ and temporal lobes $(n=17,32.1 \%)$. We observed the IDH1 mutation in 20 patients (37.7\%), MGMT methylation in 13 patients, and the unmethylated MGMT promotor in 40 patients. Furthermore, 37 patients received a standard treat-

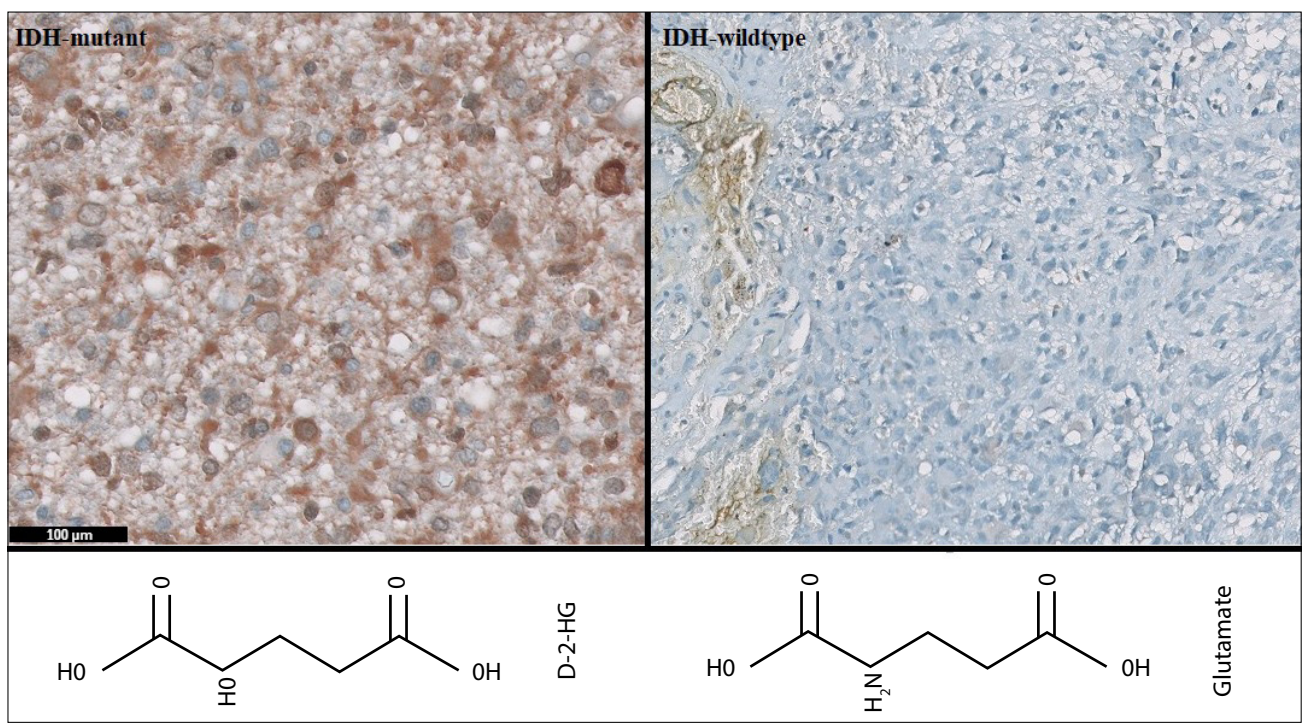

Fig. 1. The expression of the isocitrate dehydrogenase 1 (IDH1) in glioblastoma-associated epilepsy. The positively expressed IDH1 mutant (left) and the negative wild-type IDH1 (right). Scale bar: $100 \mu \mathrm{m}$. 
Table 1. Characteristics of patients and therapies

\begin{tabular}{|c|c|c|}
\hline & \multicolumn{2}{|c|}{ Overall $(n=53)$} \\
\hline & $\mathrm{n}$ & $\%$ \\
\hline \multicolumn{3}{|l|}{ Age } \\
\hline Mean (SD) & 51.4 & 17.6 \\
\hline \multicolumn{3}{|l|}{ Gender } \\
\hline Female & 17 & 32.1 \\
\hline Male & 36 & 67.9 \\
\hline \multicolumn{3}{|l|}{ Tumor location } \\
\hline Frontal & 21 & 39.6 \\
\hline Occipital & 2 & 3.8 \\
\hline Parietal & 13 & 24.5 \\
\hline Temporal & 17 & 32.1 \\
\hline \multicolumn{3}{|l|}{ Anti-epileptic drug } \\
\hline Carbamazepine & 1 & 1.9 \\
\hline Levetiracetam & 23 & 43.4 \\
\hline Levetiracetam+Carbamazepine & 2 & 3.8 \\
\hline Levetiracetam+Lacosamide & 1 & 1.9 \\
\hline Levetiracetam+Lamotrigine & 3 & 5.7 \\
\hline Levetiracetam+Phenytoin & 5 & 9.4 \\
\hline Levetiracetam+Valproic acid & 2 & 3.8 \\
\hline Phenytoin & 12 & 22.6 \\
\hline Others & 2 & 3.8 \\
\hline Phenytoin+Lacosamide & 2 & 3.8 \\
\hline \multicolumn{3}{|l|}{ Epilepsy control status } \\
\hline Unknown & 1 & 1.9 \\
\hline Controlled & 36 & 69.2 \\
\hline Uncontrolled & 16 & 30.8 \\
\hline \multicolumn{3}{|l|}{ IDH1 Mutation } \\
\hline IDH mutant & 20 & 37.7 \\
\hline IDH wild type & 26 & 49.1 \\
\hline Undetermined & 7 & 13.2 \\
\hline \multicolumn{3}{|l|}{ MGMT profile } \\
\hline MGMT hypermethylation & 13 & 24.5 \\
\hline No MGMT methylation & 40 & 75.5 \\
\hline \multicolumn{3}{|l|}{ Adjuvant therapy } \\
\hline Radiation and chemotherapy & 37 & 69.8 \\
\hline Radiotherapy & 16 & $(30.2$ \\
\hline \multicolumn{3}{|l|}{ Chemotherapy } \\
\hline Temozolomide & 29 & 78.4 \\
\hline Temozolomide plus others & 8 & 21.6 \\
\hline \multicolumn{3}{|l|}{ Recurrence status } \\
\hline No recurrence & 21 & 39.6 \\
\hline Recurrence & 32 & 60.4 \\
\hline
\end{tabular}

IDH1: Isocitrate dehydrogenase 1; MGMT: Mutation O-methylguanine-DNA methyltransferase; SD: Standard deviation.

ment protocol of chemoradiotherapy, whereas 16 patients received only radiotherapy. Of those who received chemotherapy, 29 (78.4\%) patients received TMZ alone, and eight

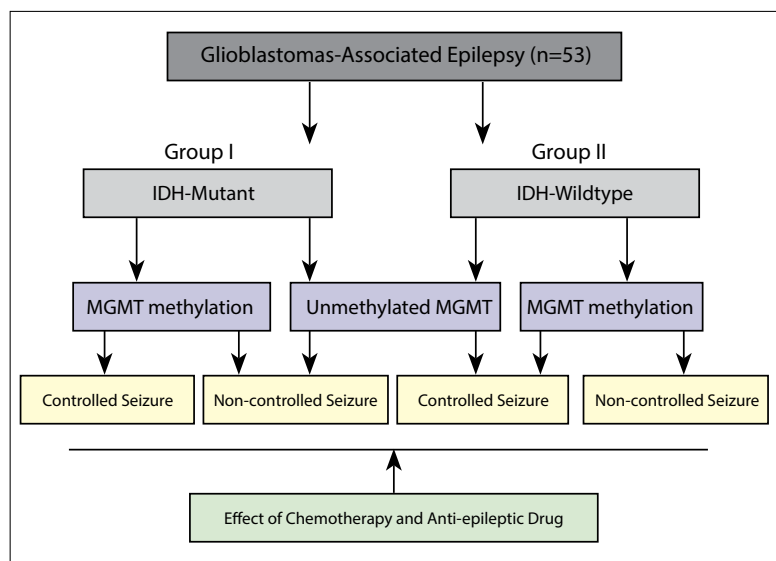

Fig. 2. The algorithm of the study objectives. Cases with glioblastoma-associated epilepsy were stratified into subdivided groups based on the isocitrate dehydrogenase 1, O-methylguanine-DNA methyltransferase methylation, and seizure control.

(21.6\%) patients received TMZ together with other chemotherapies. Epilepsy was controlled in 36 patients (69.2\%), and 16 patients (30.8\%) had uncontrolled epilepsy. Table 1 and Figure 2 summarize the descriptive distribution of the data and the study plan.

Statistical analysis- The IDH1 mutation and MGMT methylation with seizure control- Although the IDH1 mutation was significantly present in glioblastoma patients with controlled seizure $(p=0.002$; Fig. $3 a$ and $b)$, there was no significant difference in seizure control between cases with mutant or wt IDH1 ( $p=0.085$; Table 2). However, the unmethylated MGMT promotor was significantly more abundant in patients with controlled seizure than in MGMT methylated patients; a significant relationship in seizure control was found between different groups of MGMT methylation ( $p=0.037)$. Although seizure in patients with the IDH1 mutation and unmethylated MGMT promotor were significantly controlled ( $p=0.002$; Fig. $3 c$ and $d$ ), there was no significant difference in seizure control among unmethylated MGMT cases with mutant and wt IDH1.

The relationship between the IDH1 mutation and MGMT methylation with different types of anti-epileptic drugs and seizure control- Regardless of the status of the IDH1 mutation and MGMT profile, there were no significant differences in seizure control among cases treated with different anti-epileptic drugs ( $p=0.737$; Table 3 ). However, levetiracetam showed significantly better seizure control in cases with the IDH1 mutation and unmethylated MGMT promotor than in cases with methylated MGMT ( $p=0.002$; Fig. 4). 


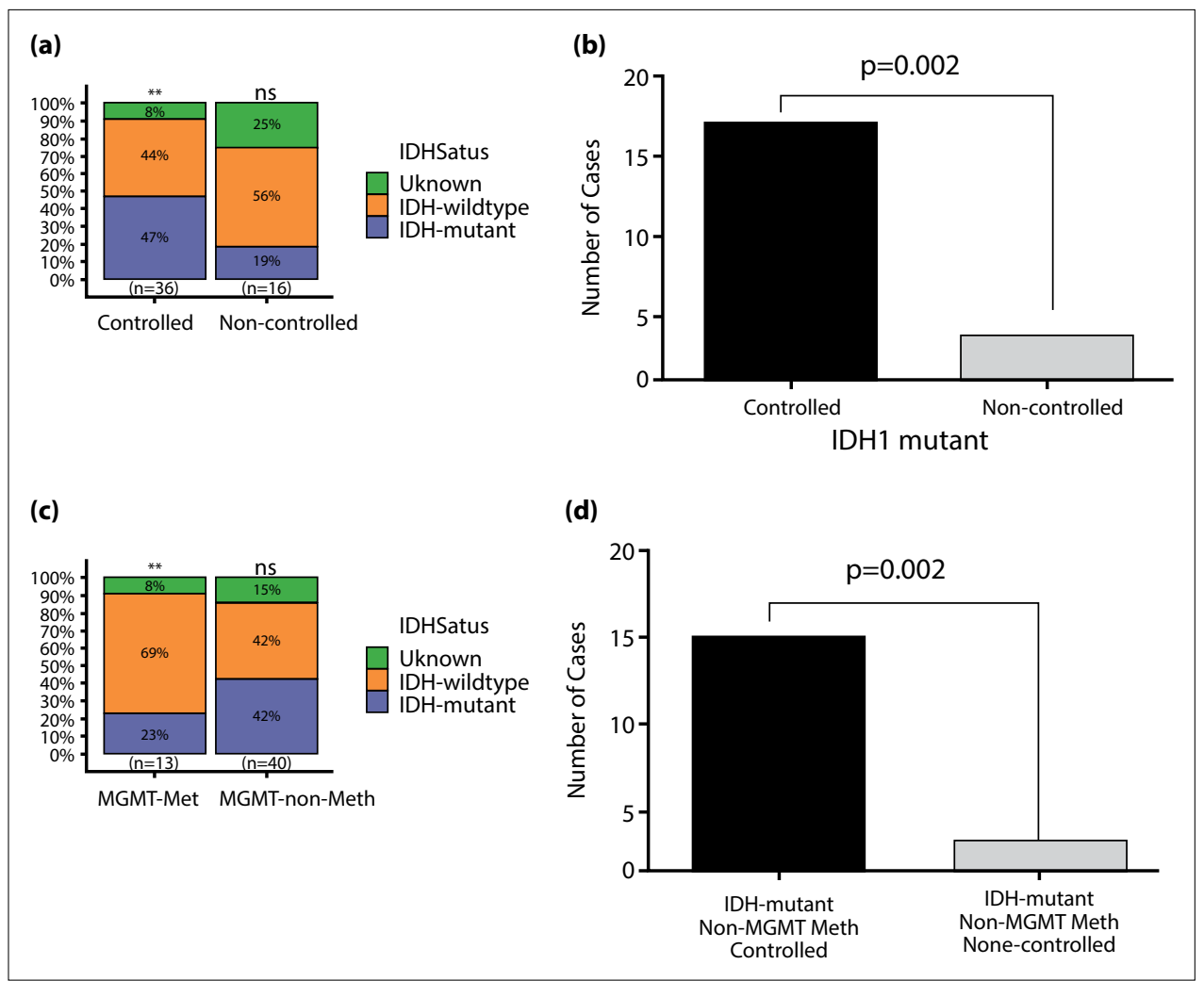

Fig. 3. The isocitrate dehydrogenase 1 (IDH1) and O-methylguanine-DNA methyltransferase (MGMT) methylation with seizure control. The IDH1 mutation is significantly present in glioblastoma patients with controlled seizure $(\mathbf{a}, \mathbf{b})$. Seizure in patients with the IDH1 mutation and unmethylated MGMT promotor was significantly controlled $(\mathbf{c}, \mathbf{d})$.

There were no significant differences in seizure control among cases with wt IDH1, regardless of the MGMT profile.

The relationship between anti-epileptic drugs and chemotherapies with seizure control and the tumor recurrence interval- There was no significant relationship between chemotherapies and anti-epileptic drugs with seizure control ( $p=0.486$; Table 4). Our analysis also showed no significant difference in seizure control among cases treated with TMZ $(p=1.6)$, levetiracetam $(p=0.25), T M Z$ plus levetiracetam $(p=0.8)$, or $\mathrm{TMZ}$ plus phenytoin $(p=0.75)$. Moreover, there was no significant difference in the tumor recurrence interval in glioblastoma patients receiving chemotherapeutic agents with controlled or uncontrolled epilepsy $(p=0.88$; Table 5; Figs. 5, 6).

Table 2. Seizure control in cases with IDH1 mutation and MGMT promotor methylation. There were no significant differences between seizure control and IDH1 status among cases with glioblastoma-associated epilepsy. However, a significant relationship in seizure control was found between different groups of MGMT methylation

Seizure control status

\begin{tabular}{lcccc}
\hline Molecular profile & Controlled & Uncontrolled & Total $(\mathrm{n}=53)$ & $\mathrm{p}$-value \\
\hline IDH1-mutant, $\mathrm{n}(\%)$ & $17.0(85.0)$ & $3.0(15.0)$ & $16.0(69.2)$ & 0.0851 \\
IDH1-wildtype, $\mathrm{n}(\%)$ & $16.0(64.0)$ & $9.0(36.0)$ & $13.0(25.0)$ & 0.0371 \\
Methylated MGMT, $\mathrm{n}(\%)$ & $6.0(16.7)$ & $7.0(43.8)$ & $39.0(75.0)$ & \\
Unmethylated MGMT, $\mathrm{n}(\%)$ & $30.0(83.3)$ & $9.0(56.2)$ & \\
\hline
\end{tabular}

Unknown cases are not included in this table. Pearson's Chi-squared test1. IDH1: Isocitrate dehydrogenase 1; MGMT: Mutation O-methylguanine-DNA methyltransferase. 
Table 3. The relationship of anti-epileptic drugs and seizure control, regardless of the status of the IDH1 mutation and MGMT promotor methylation. There were no significant differences in seizure control among cases treated with levetiracetam, phenytoin, or levetiracetam with phenytoin

\begin{tabular}{lcccc}
\hline Anti-epileptic drugs & Controlled $(\mathrm{n}=36)$ & Uncontrolled $(\mathrm{n}=16)$ & Total $(\mathrm{n}=52)$ & $\mathrm{p}$-value \\
\hline Levetiracetam, $\mathrm{n}(\%)$ & $17.0(47.2)$ & $5.0(31.2)$ & $22.0(42.3)$ & $0.737^{1}$ \\
Phenytoin, $\mathrm{n}(\%)$ & $8.0(22.2)$ & $4.0(25.0)$ & $12.0(23.1)$ & \\
Levetiracetam+Phenytoin, $\mathrm{n}(\%)$ & $3.0(8.3)$ & $2.0(12.5)$ & $5.0(9.6)$ & \\
Others, $\mathrm{n}(\%)$ & $8.0(22.2)$ & $5.0(31.2)$ & $13.0(25.0)$ & \\
\hline
\end{tabular}

Pearson's Chi-squared test'. IDH1: Isocitrate dehydrogenase 1; MGMT: Mutation O-methylguanine-DNA methyltransferase.

Table 4. The relationship between anti-epileptic drugs and chemotherapies with seizure control. Patients with glioblastoma-associated epilepsy, regardless of the type of anti-epileptic drugs and chemotherapies, showed no significant differences in seizure control

\begin{tabular}{lcccc}
\hline Seizure control status & & & \\
\hline Type of chemotherapy & Controlled & Uncontrolled & Total & p-value \\
\hline Anti-Epileptic Drugs+Temozolomide, $\mathrm{n}(\%)$ & $21.0(80.8 \%)$ & $7.0(70.0 \%)$ & $28.0(77.8 \%)$ & $0.486^{1}$ \\
Anti-Epileptic Drugs+Temozolomide plus Other, $\mathrm{n}(\%)$ & $5.0(19.2 \%)$ & $3.0(30.0 \%)$ & $8.0(22.2 \%)$ & \\
\hline
\end{tabular}

Unknown cases are not included in this table. Pearson's Chi-squared test ${ }^{1}$.

\section{Discussion}

Secondary epilepsy is a common manifestation of infiltrative gliomas and occurs in high-grade gliomas less commonly than in low-grade gliomas; however, the reason for this association remains unclear. Patients with temporal and frontal gliomas are more likely to present with seizures, and low-grade gliomas with oligodendroglial morphology are strongly associated with pre-operative seizures. Approximately $30 \%$ of gliomas are drug-resistant even after surgical resection; ${ }^{[1-3]}$ however, the underlying mechanisms of this finding are still not well understood. It is likely that epilepsy rates are not explained by peritumoral changes and that the

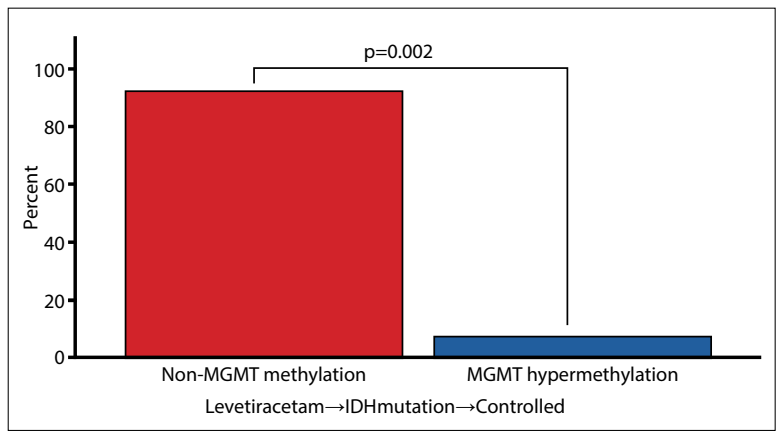

Fig. 4. Levetiracetam shows significantly more seizure control in cases with the isocitrate dehydrogenase 1 and unmethylated O-methylguanine-DNA methyltransferase (MGMT) promotor than in cases with methylated MGMT. internal relationship of genetic factors of the peritumoral brain tissue could be the cause for these seizure activities. ${ }^{[4]}$ Several studies suggested that epileptogenesis is actually influenced by tumor genetic markers. ${ }^{[5,6]}$ Another study also found that tumor growth may stimulate the epileptic focus, suggesting that both conditions may share common pathogenic mechanisms. ${ }^{[5,6]}$ Another possible explanation is the association of gliomas with the IDH1 mutation. Studies showed that mutant IDH1 gliomas are more likely to cause seizures than wt-IDH1 ${ }^{[6]}$ IDH1 is a metabolic enzyme located in the cytosol catalyzing the oxidative decarboxylation of isocitrate to a-ketoglutarate. Its mutation reduces a-ketoglutarate to D-2-hydroxyglutarate. Hence, overproduction of D-2-hydroxyglutarate may be involved in the mechanism of neuronal excitation leading to seizures ${ }^{[7,8]}$ (Fig. 1).

While the association of the IDH1 mutation with pre-operative seizures was extensively reported ${ }^{[9-14]}$ the influence of the IDH1 mutation in the post-operative glioma microenvironment is not yet clarified. Chen et al. ${ }^{\left[{ }^{[1]}\right.}$ found that seizures are more likely to be seen in patients with low-grade glioma and $\mathrm{IDH} 1$ mutation and/or 1p19q codeletion than in high-grade gliomas with the IDH1 mutation. However, epilepsy during the end-of-life phase in glioblastoma patients became uncontrolled. ${ }^{[15-17]}$ Yang et al. ${ }^{[18]}$ studied the relationship of 172 gliomas with epilepsy and found that $27 \%$ of glioblastomas were associated with epilepsy but that $64 \%$ of these epilepsy patients had low-grade gliomas. Furthermore, IDH1-mutant gliomas were associated with pre-operative seizure mainly in 
Table 5. The relationship between seizure control in glioblastoma patients and tumor recurrence interval. Patients with glioblastoma-associated epilepsy, regardless of the status of seizure control, showed no significant differences in the recurrence interval

\begin{tabular}{lcccc}
\hline Tumor recurrence interval & & & \\
\hline Seizure control status & Before 1 year $(n=30)$ & After 1 year $(n=23)$ & Total $(n=53)$ & $p$-value \\
\hline Controlled, $n(\%)$ & $21.0(70.0)$ & $15.0(68.2)$ & $36.0(69.2)$ & $0.888^{1}$ \\
Uncontrolled, $n(\%)$ & $9.0(30.0)$ & $7.0(31.8)$ & $16.0(30.8)$ & \\
\hline
\end{tabular}

Pearson's Chi-squared test ${ }^{1}$.

cases of Grade II gliomas but not glioblastomas. Our current study also found that the IDH1 mutation is significantly associated with controlled epilepsy in glioblastoma patients.

At present, several therapeutic strategies failed to control seizure activity in up to a third of patients with glioblastomas thus, a better understanding of the risk factors and mechanisms associated with glioma-associated epilepsy are needed to improve patient quality of life. To the best of our knowledge, although gliomas with MGMT gene promoter methylation are known to be more treatment-sensitive to TMZ chemotherapy, the association of glioma-associated epilepsy and MGMT promotor methylation has never been extensively studied. The relationship between pre-operative and post-operative seizure control, in regard to MGMT gene promotor methylation status, is also limited. Patients with low expression of MGMT protein or MGMT methylated gliomas had more frequent postoperative seizure control than those with non-methylated MGMT or high MGMT protein activity. ${ }^{[11,12]}$ The observed favorable postoperative seizure control in those with MGMT promotor methylation arises from the better response to adjuvant chemoradiation in this patient population. Nevertheless, these findings did not clarify whether MGMT methylation was the main reason for post-operative seizure control or whether anti-epileptic drugs act as potent MGMT methylation inhibitors. The results of our current study have demonstrated that the unmethylated MGMT promotor had more significant seizure control.

Bobustuc et al. ${ }^{[12]}$ reported that levetiracetam was the most potent MGMT inhibitor among several anti-epileptic medications and is thus considered the first-line drug to control seizure in glioma patients receiving TMZ.This is because levetiracetam enhances P53-mediateed MGMT inhibition, which increase sensitivity of glioblastoma cells to TMZ. This mechanism has never been investigated thoroughly, and thus further studies are necessary.

Scattered studies found that levetiracetam and valproic acid are the main anti-epileptic drugs that showed antitumor effects and have shown an actual decrease in the mortality rate among glioblastoma patients with epilepsy. ${ }^{[13-15]}$ Valproic acid exhibits antitumor effects through inhibition of $\mathrm{mSin} 3 \mathrm{~A} /$ histone deacetylase 1 and modulation of the mitogen-activated protein kinase pathway. In addition, due to the radio-sensitizing properties of valproic acid, radiotherapy with valproic acid is more effective than radiotherapy with other drugs. ${ }^{[19]}$ Another study on 418 patients with glioblastoma-associated seizures in Korea found that levetiracetam treatment in cases with the methylated MGMT pro-

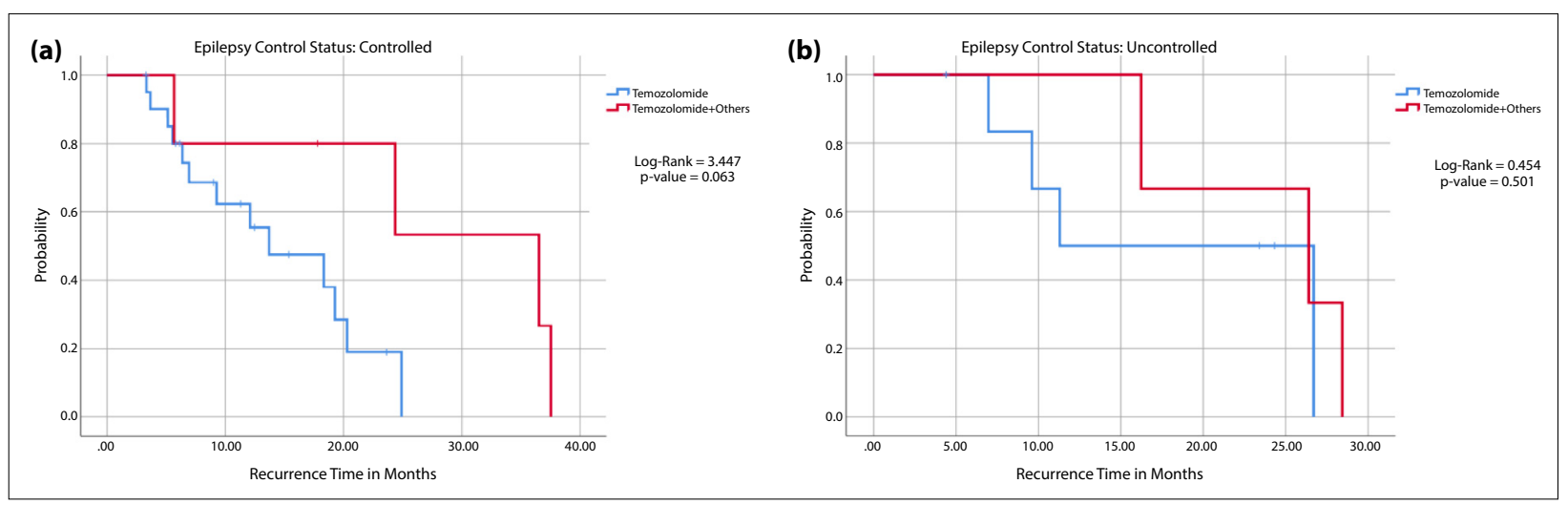

Fig. 5. (a, b) The relationship between seizure control and chemotherapies with the tumor recurrence interval, illustrated by Kaplan-Meier analyses. There is no significant difference in the tumor recurrence interval between glioblastoma patients receiving chemotherapeutic agents regardless of the status of seizure control. 
moter positively influenced the overall survival rate. ${ }^{[15]}$ In our study, we also found that levetiracetam is the first-line drug for glioblastoma-associated epilepsy. However, we reject the idea that levetiracetam sensitizes glioblastoma cells to chemotherapy, as there was no significant relationship with tumor recurrence interval when both anti-epileptic drugs and chemotherapies were used in glioblastoma patients.

Conclusion- Our study has come to three main conclusions. First, glioblastoma-associated epilepsy can be better controlled in patients with the IDH1 mutation or unmethylated MGMT promotor than in patients with the methylated MGMT promotor. Second, levetiracetam can be considered the firstline anti-epileptic drug for controlling seizures yet may not enhance the sensitivity of glioblastomas to chemotherapies. Third, the lack of seizure control in glioblastoma patients is not related to tumor recurrence despite 1-year treatment with anti-epileptic drugs. We recommend using IDH1 and the MGMT gene promotor as parameters in seizure control. We also recommend using levetiracetam as first-line treatment, regardless of the type of chemotherapeutic agent.

Informed Consent- Written informed consent was obtained from patients who participated in this study.

Ethics Committee Approval- This study was ethically approved by the National Biomedical Ethics Committee at King Abdulaziz University (Date: 08.12.2020, Decision No: HA-02-J-008).

Peer-review- Externally peer-reviewed.

Authorship Contributions- Concept: M.K.; Design: M.K., S.B.; Supervision: M.K., T.A.; Data collection \&/or processing: M.B., A.S., N.A., A.L., Y.M.; Analysis and/or interpretation: N.S.B., F.A., S.H., T.A.; Literature search: B.A., A.B.; Writing: R.S., S.H., Y.M., B.A., A.B.; Critical review: M.K., S.B.

Conflict of interest- The authors declare that they have no conflict of interest.

Financial Disclosure: The authors declared that this study has received no financial support.

\section{References}

1. Chen H, Judkins J, Thomas C, Wu M, Khoury L, Benjamin CG, et al. Mutant IDH1 and seizures in patients with glioma. Neurology 2017;88(19):1805-13. [CrossRef]

2. Van Breemen MS, Wilms EB, Vecht CJ. Epilepsy in patients with brain tumours: Epidemiology, mechanisms, and management. Lancet Neurol 2007;6(5):421-30. [CrossRef]

3. Goldstein ED, Feyissa AM. Brain tumor related-epilepsy. Neurol Neurochir Pol 2018;52(4):436-5. [CrossRef]

4. De Groot M, lyer A, Zurolo E, Anik J, Heimans JJ, Boison D, et al. Overexpression of ADK in human astrocytic tumors and peritumoral tissue is related to tumor-associated epilepsy. Epilepsia
2012;52(4):58-66. [CrossRef]

5. Huberfeld G, Vecht CJ. Seizures and gliomas: Towards a single therapeutic approach. Nat Rev Neurol 2016;12(4):204-16.

6. Feyissa AM, Worrell GA, Tatum WO, Mahato D, Brinkmann BH, Rosenfeld $S$, et al. High-frequency oscillations in awake patients undergoing brain tumor-related epilepsy surgery. Neurology 2018;90(13):e1119-25. [CrossRef]

7. Zhong Z, Wang Z, Wang Y, You G, Jiang T. IDH1/2 mutation is associated with seizure as an initial symptom in low-grade glioma: A report of 311 Chinese adult glioma patients. Epilepsy Res 2015;109:100-5. [CrossRef]

8. Feyissa AM, Worrell GA, Tatum WO, Chaichana KL, Jentoft $\mathrm{ME}$, Caxares HG, et al. Potential influence of IDH1 mutation and MGMT promotor methylation on glioma-related preoperative seizures and postoperative seizure control. Seizure 2019;69:293-89. [CrossRef]

9. Vecht $\mathrm{CJ}$, Kerkhof M, Duran-Pena A. Seizure prognosis in brain tumors: New insights and evidence-based management. Oncologist 2014;19(7):751-9. [CrossRef]

10. WickW, Weller M, van den Bent M, Sanson M, Weiler M, VonDeimling A, et al. MGMT testing: The challenges for biomarker-based glioma treatment. Nat Rev Neurol 2014;10(7):372-85. [CrossRef]

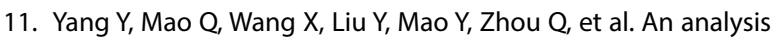
of 170 glioma patients and systemic review to investigate the association between IDH-1 mutations and preoperative glioma-related epilepsy. J Clin Neurosci 2016;31:56-62. [CrossRef]

12. Bobustuc G, Baker CH, Limaye A, Jenkins W, Pearl G, Avageropoulos $\mathrm{N}$, et al. Levitirecetam enhances P53-mediated MGMT inhibition and sensitizes glioblastoma cells to temozolomide. Neurol Oncol 2010;12(9):917-27. [CrossRef]

13. Turkalp Z, Karamchandani J, Das S. IDH mutation in glioma: New insights and promises for the future. JAMA Neurol 2014;71(10):1319-25. [CrossRef]

14. Sanson M, Marie Y, Paris S, Idbaih A, Laffair J, Ducray F, et al. Isocitrate dehydrogenase 1 codon 132 mutation is an important prognostic biomarker in gliomas. J Clin Oncol 2009;27(25):4150.

15. Ryu JY, Lok Min K, Chang MJ. Effect of anti-epileptic drugs on the survival of patients with glioblastoma multiform: A retrospective, single-center study. PLoS One 2019;14(12):e0225599.

16. De Robles $P$, Fiest KM, Frolkis AD, Pringsheim T, Atta C, Germain-Smith $C$, et al. The worldwide incidence and prevalence of primary brain tumors: A systematic review and meta-analysis. Neuro Oncol 2014;17(6):776-83. [CrossRef]

17. Pace A, Metro G, Fabi A. Supportive care in neurooncology. Curr Opin Oncol 2010;22(6):621-6. [CrossRef]

18. Yang P, Liang T, Zhang C, Cai J, Zhang W, Chen B, et al. Clinicopathological factors predictive of postoperative seizures in patients with gliomas. Seizure 2016;35:93-9. [CrossRef]

19. Shamji MF, Fric-Shamji EC, Benoit BG. Brain tumors and epilepsy: Pathophysiology of peritumoral changes. Neurosurg Rev 2009;32(3):275-85. [CrossRef] 